\title{
Instagram as an Effective Promotion Tool to Event Jogja International Batik Biennale 2018
}

\author{
$1^{\text {st* }}$ Adhianty Nurjanah \\ Communication Science \\ Universitas Muhammdiyah of Yogyakarta \\ Yogyakarta, Indonesia \\ adhianty.nurjanah@yahoo.co.id, \\ adhianty@umy.ac.id
}

\author{
$2^{\text {nd }}$ Riski Apriliani \\ Communication Science \\ Universitas Gadjah Mada \\ Yogyakarta, Indonesia \\ riskiapriliani@mail.ugm.ac.id
}

\begin{abstract}
National Crafts Council (Dekranas) DIY to promote batik as an Indonesian cultural heritage by organizing the Jogja International Batik Biennale (JIBB) 2018 event to retain the title of Yogyakarta as the World Batik City given by the World Craft Council (WCC). The number of social media users, especially Instagram in Indonesia, can support the dissemination of information, including in promoting international events. The event marketing section is an important part. in this research, the researchers want to find out the roles of Instagram is in promoting international standard cultural events at the Jogja International Batik Biennale. This study uses a descriptive qualitative method to describe how the DIY National Crafts Council used Instagram to promote the Jogja International Batik Biennale event with the aim of maintaining the title of Yogyakarta World Batik City. The result, Instagram the way easy to distribute quicly to promote JIBB Event with any features.
\end{abstract} Event

Keywords- Instagram, Effective, Promote International

\section{INTRODUCTION}

The City Government of Yogyakarta is intensively maintaining the culture in Yogyakarta[1]. Website that the Governor of DIY will provide support to activists, observers, and preservers of the cultural heritage of DIY ancestors. One of them is the National Crafts Council (Dekranas) DIY to promote batik as an Indonesian cultural heritage by organizing the 2018 Jogja International Batik Biennale event to retain the title of Yogyakarta as the World Batik City given by the World Craft Council (WCC).

In 2018, the JIBB event was held for the second time with a significant increase compared to 2016. The arrangement of this event cannot be separated from marketing communication activities included in the activities of below the line[2]. The success of the 2018 JIBB event is closely related to the promotion strategy implemented at the 2018 Jogja International Batik Biennale event, especially through new media that is able to facilitate the promotion of international cultural events.

Facilitation that is supported by advances in communication technology enables interactive communication through social media. According to Maria Verniccio[3], Communicating brands through social media implies a new collaborative strategy based on two fundamental approaches: interactivity (Gupta et al., 2010; Simmons, Thomas, \& Truong, 2010) and openness (Mairinger, 2008; Pitt, Watson, Berthon, Wynn, \& Zinkhan, 2006). Stakeholders increasingly interact with firms and with each other, challenging the company's dominant role in the corporate brand-creation process. Verniccio[3] sais if there are three principal ways (no alternative) to capitalize on the strengths of social media for brand-building purposes, having first fully understood their particular functional dynamics. These approaches are the following:

- Using existing social media in public relations programs to reach new online opinion leaders, such as bloggers and podcasters, and inform them about products and services, societal initiatives, or innovations;

- 2. Using social media to listen to the voices of the stakeholders in discussions focused on topics relevant to the firm;

- 3. Initiating direct interactive platforms, feeding them with input from employees and managers, and using these one-to-one and many-to-many forms of communication to establish, maintain, and reinforce the brand's connections, image, and reputation.

The presence of social media can facilitate its users in communicating, accessing information, and self-actualizing; one of the vivid examples being Instagram. As the data obtained from the results of the Hootsuite survey, Instagram with 62 million users is ranked 4th in terms of social media platform with most users in Indonesia in 2019[4].

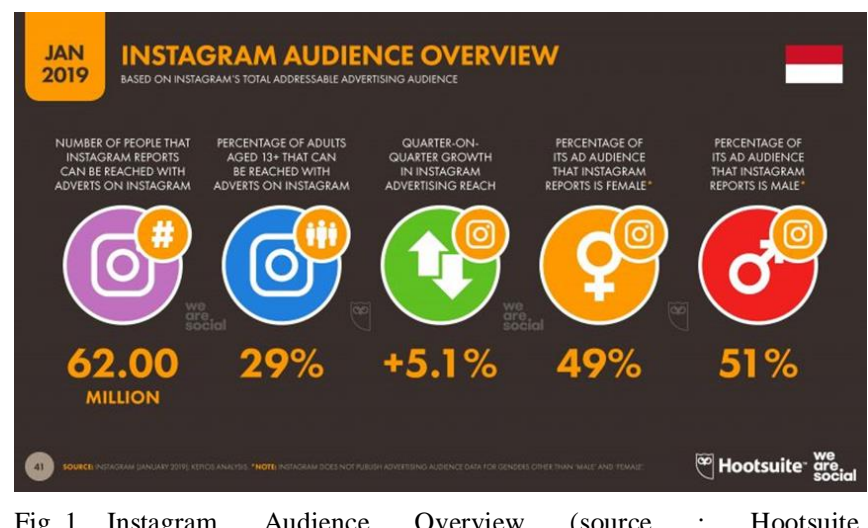

https://websindo.com/indonesia-digital-2019-media-sosial/)

The number of social media users, especially Instagram in Indonesia, can support the dissemination of information, including in promoting international events. The event marketing section is an important part. This will relate to the number of visitors or participants at the event to be held. The number of visitors will be influenced by how information about the event reaches the precise target. So it takes detailed planning on the promotion of the event. 
Instagram is getting popular as an application that is functioned to share photos, resulting in the increasing number of users that jumped into the business account that promote its products through Instagram[5]

Instagram is a photo sharing application and taking pictures or photos that apply digital filters to change the appearance of photo effects, and share them on various social media services, including Instagram itself. Instagram has five main menus, all of them are located at the bottom of the display page, namely Home Page, Comments, Explore, Profile, and News Feed[6]

Features that the researchers found on Instagram for communication or promotional activity, such as Posting Photos, Videos, Live Videos, Comments, Direct Messages, Instagram Stories / Instastory, and Insight that are able to provide in-depth information about the demographics of followers. Besides analyzing the details of each post (content) such as the number of likes, reach, impressions, saved, shares, and comments[7].

From various reasons, in this research, the researchers want to find out the roles of Instagram is in promoting international standard cultural events at the Jogja International Batik Biennale.

\section{METHODS}

This research uses a qualitative approach with positivistic paradigm on the research object Media@BatikBiennale to promote the 2018 Jogja International Batik Biennale event. Qualitative data analysis requires researchers to carry out activities simultaneously with data collection, data interpretation and writing research reports[8]. This study uses a descriptive qualitative method to describe how the DIY National Crafts Council used Instagram to promote the Jogja International Batik Biennale event with the aim of maintaining the title of Yogyakarta World Batik City. Descriptive qualitative research wants to describe, various situations, which become the object of research[9].

\section{RESULT AND DISCUSSION}

Awareness of the use of new media in the name of Instagram in promoting a post can be said as a solution to promote the message widely and effectively but at a lower price. Features that are used by Dekranas DIY JIBB to promote events in Instagram[10] such as the following:

\section{A. Posting Photos}

Photo content that is applied to the @BatikBiennale account as a form of promotion that educates the public on the predicate obtained by Yogyakarta as the World Batik City. This is also supported by a caption that explains the JIBB event and the predicate of Yogyakarta World Batik City.

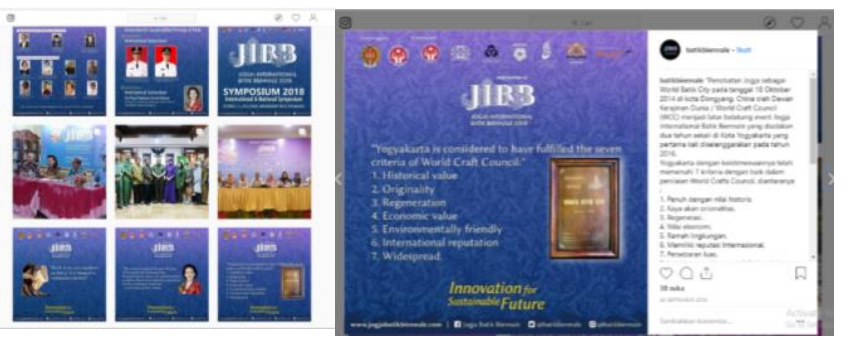

Fig. 2. Figure 2: Instagram Photo Content (source: Instagram @BatikBiennale)

According to Aisha Wai Yasmina, as the 2018 JIBB Communication Strategic event, she explained that this approach would be more effective because at the beginning the content provided was not directly hard selling, but soft selling by providing education in advance the background of the JIBB event in order to encourage the public to participate in the event JIBB 2018.

\section{1) The Video}

Video posting is a form of audio and visual interaction. This video content provides an overview of the 2018 JIBB event series and the caption has invited the public to participate in the 2018 JIBB event.

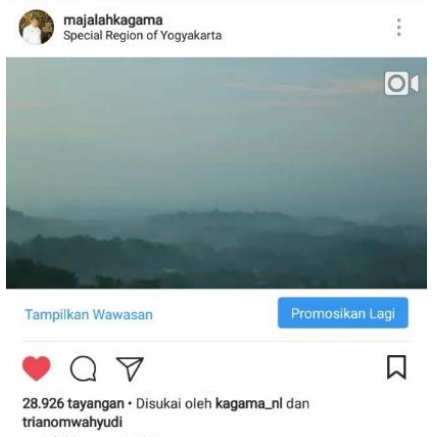

Fig. 3. Video Posts (source: Documents of the 2018 JIBB Committee)

\section{2) Comment}

The account of @ BatikBiennale also opens for comments and is very friendly in answering questions asked by Instagram users to find out about the 2018 JIBB event.

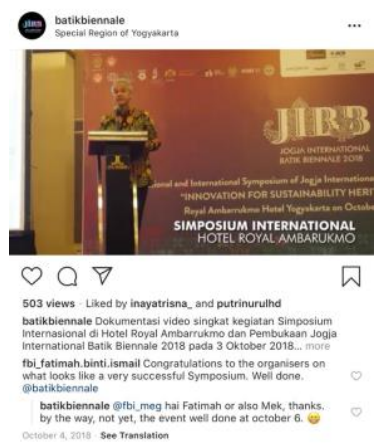

Fig. 4. Comment Activity (source : Instagram @BatikBiennale)

\section{3) Live Video}

Live videos are also used when covering a series of JIBB events, both from the Opening, Road show, Batik Festival, Symposium, Exhibitions and excerpts from several venues, Fashion Show, Carnival and Closing. This Live Video activity is then saved so that the public can also access the past live video posts. 


\section{a) Instagram Stories / Instastory}

Slightly different from posting video photos that will be seen in the feed, instagram stories are features used by JIBB events to capture the agenda before the JIBB event takes place and when the JIBB event series takes place without having to ruin the order of the feeds that has been arranged.

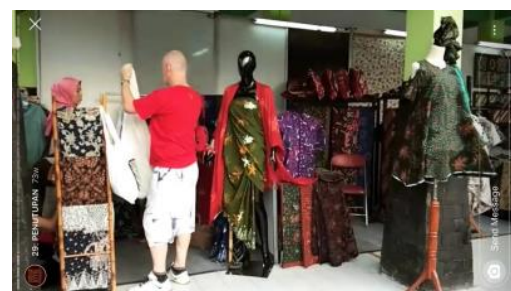

Fig. 5. Instastory Contents (source : Instagram @ BatikBiennale)

\section{4) Insight and Instagram Ads.}

The presence of Insight and Instagram Ads features is utilized by 2018 JIBB Strategic Communications namely to increase the visitors of the 2019 JIBB exhibition event. Accordingly the defined target age above 25 years which have an interest in collecting batik as recipients of the advertising. The results of the research prove that Instagram ads will give a higher impression and response to video posts than posts that only provide information in the form of photos. As mentioned in the data of the following figure:
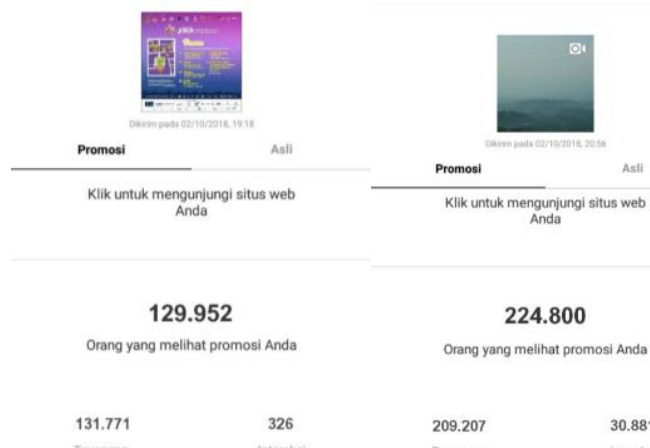

131.77
209.207

\subsection{1}

Fig. 6. Insight data results from Instagram Ads posts (source: Documents of the 2018 JIBB Committee)

Based on the results of posting photos and videos there is a comparison that video content gets more impressions than photos, this is how photos gets 129,952 viewing accounts, 131,771 views, and 326 interactions both likes and comments. While posts in the form of videos get 224,800 account impressions, the number of interaction in the form of likes and comments are 30,881 .

In photo postings, the captions and contents being selected is soft selling and it emphasizes public awareness of the predicate of Yogyakarta as the World Batik City. This was stated by Aisha as JIBB's Strategic Communication Event. "The meaning behind this content stage is important to make the community more aware with the title of the city of Yogyakarta as the World Batik City, and make people proud to finally present at the Jogja International Batik Biennale. (Aisha Wai Yasmina, Strategic Communications JIBB 2018.)"

This was acknowledged by visitors to the Jogja International Batik Biennale 2018 event, Parni Aisyiyah who also learned about JIBB event information from Instagram and she felt educated about Yogyakarta as the World Batik City.
"Through Instagram I discover about this JIBB event, and I'm more proud to be a Jogja community. Thanks to Batik, Jogja can be recognized in the eyes of the International. This event improve my insight about batik that Batik is a process that is becoming a tradition. (Parni Asfiyah, 2018 JIBB Event Exhibition Visitors)."

Besides that, photo and video challenges were made involving Jogja Influencers namely Rondweasley and Gayatri with 102k followers and @ gayaaatri with 40.7k followers which can increase posting engagement. The two accounts also joined the Jogja influencer community which has mass as well as the Top Hitz Jogja Influencer.

"The target of this promotional video is aimed for instagram users aged 15-25 years, with the character of milennial kids in Yogyakarta and surrounding areas. M hrough sale in Instagram and use these influencers so how effective to bring rapid period and many (Aisha Wai Yasmina, Strategic Communications JIBB 2018. Results January 13, 2019 interview).”

Afterward, when analyzed on the Instagram algorithm, the engagement and impression of the @BatikBiennale Instagram account will increase because the Instagram algorithm reads the intensity of accessing the @ BatikBiennale account with many visitors.

The results of the promotion through Instagram get a clear increase in the number of visitors and high awareness built on the Jogja International Batik Biennale event. This can be concluded in the following graph.

2016 \& 2018 Comparison Data

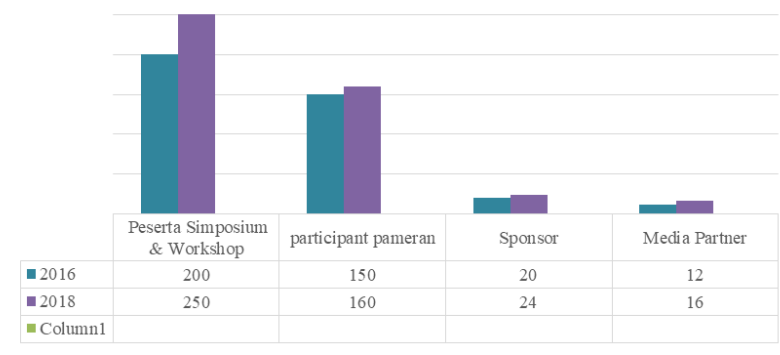

Fig. 7. 2016 \& 2018 Comparison Data JIBB (source: Data document of DIY National Crafts Council \& JIBB Committee)

Based on the data above, it can be concluded that the impact of using Instagram as media of promotions can increase awareness and it also inspires people to participate in the 2018 Jogja International Batik Biennale event.

\section{CONCLUSION}

The researcher draws the conclusion that the 2018 Jogja International Batik Biennale event is a form of international standard cultural event using social media Instagram and bellows line. Dekranas DIY optimizes the promotion of JIBB events by using Instagram Instastory features-i.e.; photos, videos, instagram ads, insights, comments, which are considered effective in promoting JIBB events in maintaining the predicate of Yogyakarta as the World Batik City at a lower cost. This is evidenced by the results of interviews with visitors and statements from JIBB strategic communication that visitors attend the JIBB event because they know information from Instagram. 
In addition to the concept of creative photo contest and collaborating with influencers, application of promotion using Instagram especially on Instagram Ads and Photo challenge features will give birth to Instagram algorithm, so engagement and impression of Instagram account @ BatikBiennale will increase due to the formula of Instagram algorithm reads the intensity of accessing @BatikBiennale account with many visitors. With more and more account accesses, contents on Instagram will be easy to distribute quickly.

\section{REFERENCES}

[1] Special District Government of Yogyakarta. DIY Government Appreciates DIY Culture Activists. Retrieved February 24, 2020https://jogjaprov.go.id/berita/detail/8172-pemda-diy-apresisasipenggiat-budaya-diy

[2] Wibowo, Arie, Namaste Event Promotion Strategy, 14 (2), 2015

[3] Vernuccio, Maria, Communicating Corporate Brands Through Social Media: An Exploratory Study, New York : Sagepub, 2014, p.215
[4] Websindo. Hootsuite : Indonesia Digital 2019 Social Media. Retrieved from https://websindo.com/indonesia-digital-2019-mediasosial/

[5] M Nisrina, Online Business, The Benefits of Social Media in Making Money, Yogyakarta; Kobis, 2015

[6] Atmoko Dwi, Bambang. Instagram Handbook Tips Fotografi Ponsel. Jakarta: Media Kita, 2012

[7] Aditama, Faris Hazim, Bajubekas_Oke Instagram Account Promotion Strategy in Increasing the Number of Followers for 2017-2018 Period, 2019

[8] Cresswell, JW. Research Design: Qualitative, Quantitative and Mixed Approaches. Third Edition. Yogyakarta: Student Library.2012

[9] Moleong, Lexy. Qualitative Research Methodology Edition: Revision. Bandung: PT. Remaja Rosdakarya.2011

[10] Instagram. @BatikBiennale.

[11] https://www.instagram.com/batikbiennale/ 